University of Wollongong

Research Online

Faculty of Engineering and Information

Faculty of Engineering and Information

Sciences - Papers: Part A

Sciences

$1-1-2013$

Behaviour of clay-fouled ballast under drained triaxial testing

Buddhima Indraratna

University of Wollongong, indra@uow.edu.au

Nayoma C. Tennakoon

University of Wollongong, nayoma@uow.edu.au

Sanjay Shrawan Nimbalkar

University of Wollongong, sanjayn@uow.edu.au

Cholachat Rujikiatkamjorn

University of Wollongong, cholacha@uow.edu.au

Follow this and additional works at: https://ro.uow.edu.au/eispapers

Part of the Engineering Commons, and the Science and Technology Studies Commons

Research Online is the open access institutional repository for the University of Wollongong. For further information contact the UOW Library: research-pubs@uow.edu.au 


\title{
Behaviour of clay-fouled ballast under drained triaxial testing
}

\author{
Abstract \\ Contamination or fouling of rail ballast with external fines, including slurried and pumped subgrade \\ material (e.g. clay and silt), is one of the primary reasons for track deterioration. Fouling causes \\ differential settlement of the track, and also decreases the load-bearing capacity, owing to the reduction \\ in the friction angle of the granular assembly. In certain circumstances, fouled ballast needs to be cleaned \\ or replaced to maintain the desired track stiffness, load-bearing capacity and track alignment, all of which \\ influence safety. This paper presents and discusses the results of a series of large-scale triaxial tests \\ conducted on latite basalt, a rail ballast of volcanic origin, commonly used in Australia. Consolidated \\ drained triaxial tests were conducted under three different levels of confining pressure and varying \\ degrees of clay fouling. Stress-strain degradation characteristics are discussed in detail. This paper also \\ describes the non-linear strength envelope and a novel empirical relationship to capture the detrimental \\ effects of clay fouling on the performance of ballasted tracks.

\section{Keywords} \\ clay, fouled, ballast, behaviour, under, testing, drained, triaxial \\ Disciplines \\ Engineering | Science and Technology Studies

\section{Publication Details} \\ Indraratna, B., Tennakoon, N. C., Nimbalkar, S. Shrawan. \& Rujikiatkamjorn, C. (2013). Behaviour of clay- \\ fouled ballast under drained triaxial testing. Geotechnique: international journal of soil mechanics, 63 (5), \\ 410-419.
}




\title{
Behaviour of clay-fouled ballast under drained triaxial testing
}

\author{
B. INDRARATNA*, N. TENNAKOON*, S. NIMBALKAR* and C. RUJIKIATKAMJORN*
}

\begin{abstract}
Contamination or fouling of rail ballast with external fines, including slurried and pumped subgrade material (e.g. clay and silt), is one of the primary reasons for track deterioration. Fouling causes differential settlement of the track, and also decreases the load-bearing capacity, owing to the reduction in the friction angle of the granular assembly. In certain circumstances, fouled ballast needs to be cleaned or replaced to maintain the desired track stiffness, load-bearing capacity and track alignment, all of which influence safety. This paper presents and discusses the results of a series of large-scale triaxial tests conducted on latite basalt, a rail ballast of volcanic origin, commonly used in Australia. Consolidated drained triaxial tests were conducted under three different levels of confining pressure and varying degrees of clay fouling. Stress-strain degradation characteristics are discussed in detail. This paper also describes the non-linear strength envelope and a novel empirical relationship to capture the detrimental effects of clay fouling on the performance of ballasted tracks.
\end{abstract}

KEYWORDS: clays; deformation; gravels; laboratory tests; particle crushing/crushability; shear strength

\section{INTRODUCTION}

Railways offer an efficient and economic transport mode in many parts of the developed world. Ballast is a free-draining granular material with adequate load-bearing capacity for 25-30 t axle trains (Selig \& Waters, 1994). It is usually composed of medium to coarse gravel-sized particles (10$60 \mathrm{~mm}$ ). Its main functions (Priest et al., 2010; Indraratna et al., 2011; Le Pen \& Powrie, 2011) are to

(a) transfer the train load from sleepers to the sub-ballast layer and subgrade with an acceptable distribution of stress with depth and associated deformation

(b) provide sufficient lateral confining pressure to the track

(c) provide a free-draining condition.

However, during track operation, fine particles can accumulate within the ballast voids, owing to

(a) breakage of angular corners and sharp edges

(b) infiltration of fines from the surface

(c) subgrade soil pumping under conditions of excessive cyclic loads and saturated soil conditions.

Fouling of ballast makes it effectively less angular, and decreases its overall shear strength. Under typical Australian track environments, the infiltration of fines from sub-ballast and subgrade accounts for up to $58 \%$ of fouling, followed by $20 \%$ surface infiltration, $20 \%$ ballast degradation, and the rest from concrete sleeper wear (Indraratna et al., 2011). Feldman \& Nissen (2002) stated that for coal freight tracks in Australia, coal dust accounts for $70-95 \%$ of the contaminants; the balance is predominantly the ballast breakdown itself.

Worldwide, the level of funds invested in track maintenance is substantial. For instance, the annual cost of removing fouled ballast has exceeded $\$ 15$ million in the state of New South Wales (Australia) alone since the mid-2000s, and annually in excess of $300000 \mathrm{t}$ of ballast is used to replace

Manuscript received 7 July 2011; revised manuscript accepted 17 May 2012. Published online ahead of print 21 September 2012.

Discussion on this paper closes on 1 September 2013, for further details see p. ii.

* Centre for Geomechanics and Railway Engineering, University of Wollongong, Centre of Excellence for Geotechnical Science and Engineering, Australia. the fouled ballast (Indraratna et al., 2011). These maintenance costs and efforts can be significantly reduced if an accurate estimation of track deterioration caused by the fouling material can be predicted. By employing an effective maintenance programme, not only the cost but also the quarrying of ballast can be reduced, with favourable environmental implications and improved productivity.

When ballast is fouled, the interaction between grain networks may change substantially as the intruded fine particles change the pore matrix of the ballast assembly, reducing the particle interlock (i.e. frictional resistance). Budiono et al. (2004) and Giannakos (2010) showed that fine particles adversely affect the strength and stiffness of the track. Also, the increased fines content may lead to excess pore water pressure generation upon saturation (Indraratna et al., 2011). When the extent of fouling becomes excessive, these fine particles can strongly influence the track behaviour, negating the favourable mechanical properties of the aggregates. As the pores are almost filled, the ballast loses its ability to drain the track superstructure effectively (i.e. reduced permeability). Under poor drainage conditions, saturation of these fines (especially pumped subgrade clay) can sustain excess pore pressures, threatening the overall track stability.

Huang et al. (2009) conducted a series of large-scale direct shear tests on both fresh and coal-fouled ballast, and verified that the overall shear strength of the fouled ballast steadily decreased with increase in fouling content. Although numerous micromechanical studies on granular materials have also been employed using discrete-element methods (Lim \& McDowell, 2005; Lu \& McDowell, 2006; Huang et al., 2010; Huang \& Tutumluer, 2011), the deformation and strength properties of fouled ballast have still not been established in detail. In this study, large-scale triaxial tests were conducted to study the stress-deformation characteristics of clay-fouled ballast.

\section{Quantifying ballast fouling}

Fouling material was initially defined as particles smaller than $9.5 \mathrm{~mm}$ accumulated in the ballast voids (Selig \& Waters, 1994). Commonly used fouling indices are the fouling index, FI, the percentage fouling (Selig \& Waters, 1994), and the percentage void contamination, PVC (Feldman \& Nissen, 2002). In the former two indices, fouling 
materials that have specific gravities significantly different from that of the parent rock (ballast) cannot be captured, leading to inaccurate volume estimations. PVC is more realistic, and is defined as the ratio of the volume of fouling material to the volume of voids within the ballast. Although the PVC method is a direct measure of the percentage of voids occupied by fouling particles, the volume of fouling material needs to be calculated after compacting (standard Proctor technique). This does not always represent the correct volume of fouling in the real track environment. In view of the above, a new parameter, the void contaminant index (VCI) is proposed, which can capture the role of different fouling materials and the corresponding void reduction as a modification to the PVC. VCI is defined as

$$
\mathrm{VCI}=\frac{V_{\mathrm{f}}}{V_{\mathrm{vb}}}
$$

where $V_{\mathrm{f}}$ is the actual volume of fouling material within the ballast voids, $V_{\mathrm{vb}}$.

By substituting the relevant soil parameters, VCI can be expressed as

$$
\mathrm{VCI}=\frac{1+e_{\mathrm{f}}}{e_{\mathrm{b}}} \times \frac{G_{\mathrm{sb}}}{G_{\mathrm{sf}}} \times \frac{M_{\mathrm{f}}}{M_{\mathrm{b}}} \times 100
$$

where $e_{\mathrm{b}}$ is the void ratio of the clean ballast, $e_{\mathrm{f}}$ is the void ratio of the fouling material, $G_{\mathrm{sb}}$ is the specific gravity of the clean ballast, $G_{\text {sf }}$ is the specific gravity of the fouling material, $M_{\mathrm{b}}$ is the mass of the clean ballast, and $M_{\mathrm{f}}$ is the mass of the fouling material.

A proper understanding of the nature of fouling materials is pertinent, irrespective of the quantity of fouling. For example, sand-size and fine-gravel-size fouling material can sometimes increase the shear strength and the stiffness of the ballast, owing to a more broadly graded mix with better compaction characteristics, thereby improving the stability and resistance to plastic strain (Selig \& Waters, 1994). In contrast, fine-grain particles such as clay and silt can reduce the shear strength by reducing the internal friction of coarse aggregates.

\section{EXPERIMENTAL PROCEDURE}

In order to understand the effect of clay fouling on the stress-strain and degradation behaviour of ballast for different levels of fouling, a series of large-scale monotonic triaxial tests were carried out for confining pressure in the range $10-60 \mathrm{kPa}$, which is representative of field conditions (Table 1). In typical Australian tracks, field measurements indicate that the lateral confining pressure provided by the sleepers, shoulder and crib ballast rarely exceeds $60 \mathrm{kPa}$ (Indraratna et al., 2010b). Suiker et al. (2005) have indicated that a confining pressure range of $10-60 \mathrm{kPa}$ would cover most in situ conditions in European tracks. Based on track maintenance records in New South Wales, the maximum fouling levels prior to replenishing with fresh ballast have

Table 1. Experimental programme for triaxial testing

\begin{tabular}{l|c|c}
\hline Test series & $\begin{array}{c}\text { Void contaminant index, } \\
\text { VCI: } \%\end{array}$ & $\begin{array}{c}\text { Confining pressure, } \\
\sigma_{3}^{\prime}: \mathrm{kPa}\end{array}$ \\
\hline 1 & 0 & $10,30,60$ \\
2 & 10 & \\
3 & 25 & \\
4 & 50 & \\
5 & 80 & \\
\hline
\end{tabular}

been in the proximity of VCI at $65 \%$. Therefore the fouled ballast tested in the current study included the range $10 \% \leqslant \mathrm{VCI} \leqslant 80 \%$.

Unlike conventional geomaterials such as sands and gravel, because of the larger physical dimensions of ballast, a large-scale triaxial apparatus that could accommodate a specimen $600 \mathrm{~mm}$ high and $300 \mathrm{~mm}$ in diameter was designed and built at the University of Wollongong. This apparatus consists of six main components: the main cylindrical chamber housing the specimen, the vertical loading unit (actuator), the servo-controller, confining and back-pressure control units, volume change measurement device and digital data acquisition system (Fig. 1). A $7 \mathrm{~mm}$ thick cylindrical rubber membrane is used to prepare and confine the specimen. Given the nature of sharp angular aggregates, the $7 \mathrm{~mm}$ membrane was thick enough to prevent puncture during specimen preparation and testing (in the past, both $3 \mathrm{~mm}$ and $5 \mathrm{~mm}$ thick membranes punctured during shearing). The Young's modulus of the membrane was determined to be $4300 \mathrm{kPa}$, following the method described by ASTM D4767-04 (ASTM, 2002) and Bishop \& Henkel (1962). The pore water pressure can be measured using miniature transducers inserted at the midplane of the specimen. Consolidated drained conditions ensured that the excess pore water pressure recorded was always insignificant during testing.

The geotechnical properties of ballast change with its initial density (or void ratio), the particle size distribution (PSD) and the degree of saturation (Indraratna et al., 1998, 2011; Suiker et al., 2005). The initial PSD, density and void ratio of the ballast were kept almost identical in all specimens to capture realistic track conditions. Fresh ballast samples were obtained from Bombo quarry (near the city of Wollongong). It was pointed out in earlier studies that as the sample size ratio (i.e. the diameter of the test specimen to the maximum particle size) exceeds 6 , sample-size effects become increasingly insignificant (Marachi et al., 1972; Indraratna et al., 1993). The PSD of the clean ballast used in this study is plotted in Fig. 2, together with the recommended Australian Standard AS 2758.7 (Standards Australia, 1996), where the maximum grain size falls between 50 and $60 \mathrm{~mm}$. Commercial kaolin was used to simulate clay fouling, and its properties are given in Table 2 .

\section{Specimen preparation}

Two specimen preparation methods were adopted for different levels of VCI. Ballast specimens were sieved and thoroughly mixed to ensure consistency of test specimens. Fig. 3 shows a schematic diagram of the fouling material filling the ballast voids.

In the first method, the clean ballast specimen was divided into four equal portions. Each portion was then placed inside the chamber (Fig. 4(a)) and compacted, using a vibrating plate, to a height of $150 \mathrm{~mm}$. A rubber pad underneath the vibrating plate was used to prevent particle breakage during placement. All layers were placed and compacted until the final height of $600 \mathrm{~mm}$ was attained. The specimen was then saturated from the base upwards.

In the second method, the amount of clay needed for a predetermined VCI was calculated for each test specimen. A quarter of the clay mixture was mixed with a quarter portion of ballast using a concrete mixer, and then placed inside the upright cylindrical membrane (Figs 4(b) and 4(c)). The moisture content of the clay during mixing was slightly higher than the liquid limit of $52 \%$. A vibrating plate was used to compact the specimen following the sequential procedure, as explained above, for the subsequent layers. Based on visual inspection, fouling material coating the 


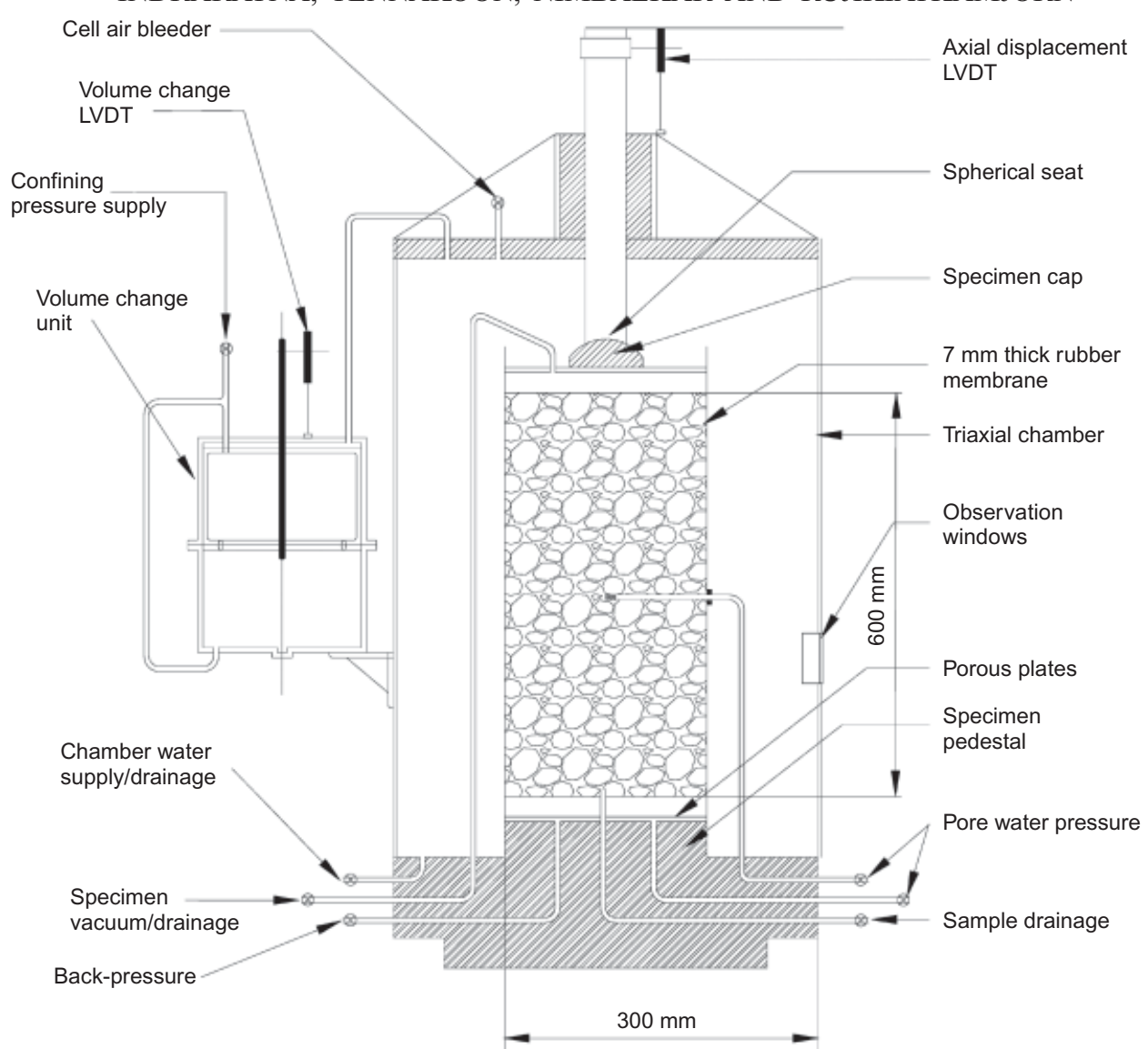

Fig. 1. Schematic illustration of large-scale triaxial chamber

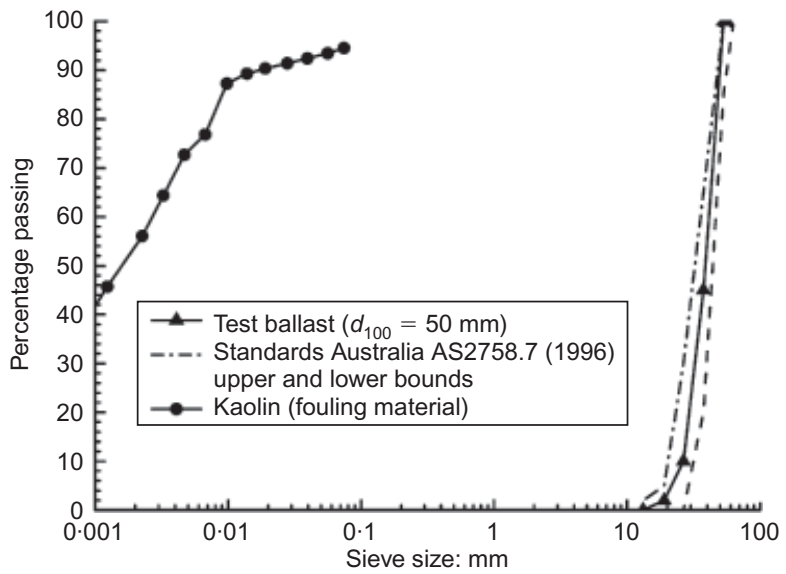

Fig. 2. Particle-size distribution of test materials

Table 2. Properties of test material

\begin{tabular}{l|c}
\hline Property & Value \\
\hline Specific gravity of ballast, $G_{\mathrm{sb}}$ & $2 \cdot 75$ \\
Specific gravity of kaolin, $G_{\mathrm{sf}}$ & $2 \cdot 51$ \\
Bulk unit weight of clean ballast: $\mathrm{kN} / \mathrm{m}^{3}$ & $14 \cdot 3$ \\
Initial void ratio of clean ballast & $0 \cdot 88$ \\
Bulk unit weight of fouling material (kaolin): $\mathrm{kN} / \mathrm{m}^{3}$ & $8 \cdot 88$ \\
Initial void ratio of fouling material (kaolin) & $1 \cdot 75$ \\
Plastic limit of kaolin: \% & $26 \cdot 4$ \\
Liquid limit of kaolin: \% & $52 \cdot 1$ \\
Uniaxial compressive strength of parent rock, $\sigma_{\mathrm{c}}: \mathrm{MPa}$ & 130 \\
\hline
\end{tabular}

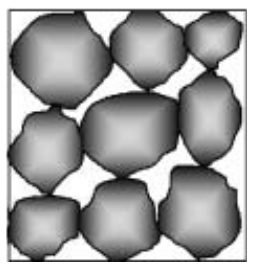

(a)

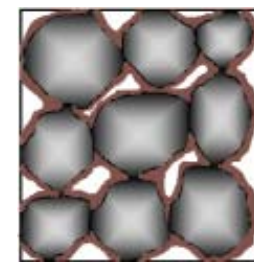

(b)

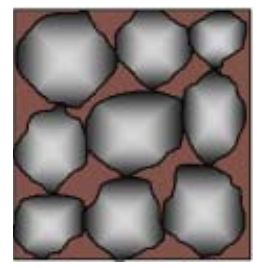

(c)
Fig. 3. Schematic diagrams of (a) clean, (b) partially fouled and (c) totally fouled ballast

entire surface area of ballast was ensured during and after the mixing process in the concrete mixer.

The effect of the membrane was considered, and corrected at two stages: (a) during specimen preparation; and (b) during specimen testing. During specimen preparation, a mild vacuum suction $(4-6 \mathrm{kPa})$, depending on VCI, was applied between the split mould and the membrane. This small suction was sufficient for the membrane to attach fully to the split mould, without transferring any significant confinement to the ballast specimen. The resulting circumferential strain of the membrane was determined to be $1 \cdot 5-2 \cdot 0 \%$. Before removing the split mould, an internal specimen suction of up to $5 \mathrm{kPa}$ was applied to the interior of the ballast specimen through the vacuum/drainage valve shown in Fig. 1 to ensure that the ballast assembly was stable: that is, with insignificant deformation from the originally prepared dimensions of $300 \mathrm{~mm}$ diameter and $600 \mathrm{~mm}$ height. The split cell was removed within 10-15 min after specimen preparation.

After preparing the test specimen, the outer cell chamber was placed and connected to the axial loading actuator (Figs 


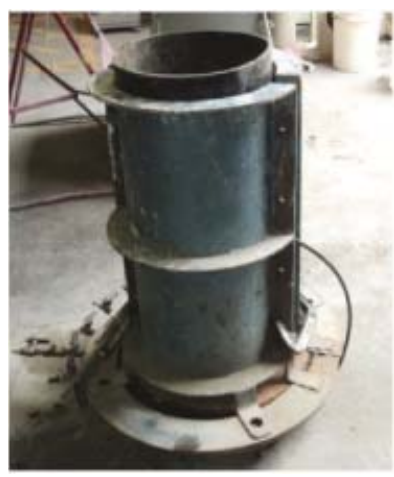

(a)

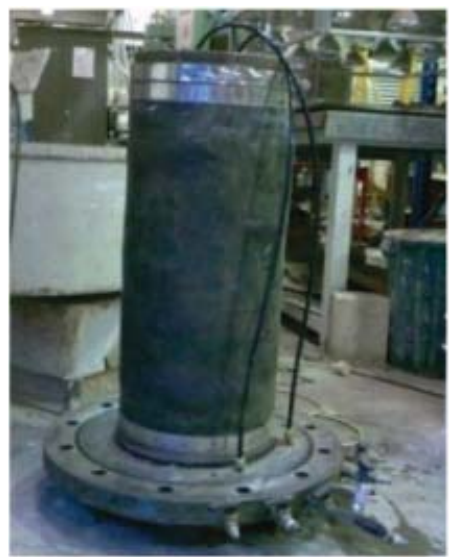

(d)

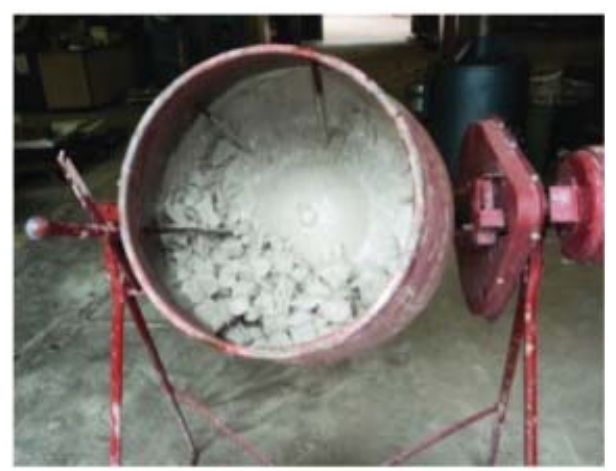

(b)

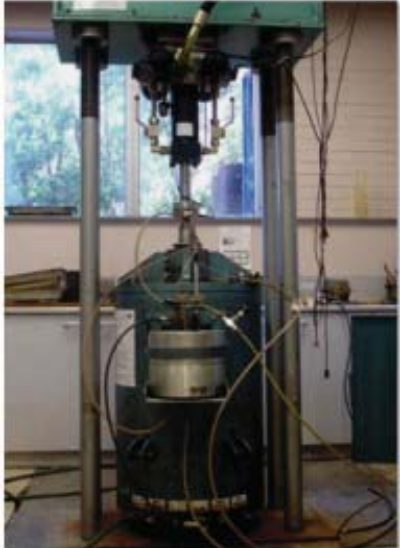

$(e)$

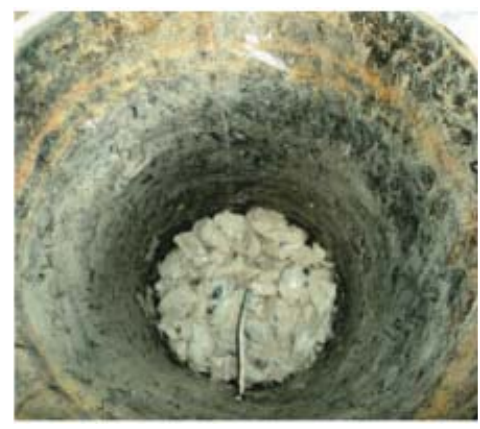

(c)

Fig. 4. Specimen preparation methods: (a) $7 \mathrm{~mm}$ thick membrane supported by two split moulds; (b) ballast mixed with kaolin; (c) first layer of fouled ballast placed within membrane; (d) completed specimen; (e) testing of specimen in large-scale triaxial rig

4(d) and 4(e)). The internal suction was maintained, and then removed once the cell pressure and back-pressure applied in tandem exceeded $5 \mathrm{kPa}$. For all tests, a backpressure of $80 \mathrm{kPa}$ was applied to obtain sample saturation with Skempton's $B$ value approaching unity $(B>0.98)$. Isotropic consolidation under the net confining pressures of $10,30,60 \mathrm{kPa}$ (Table 2) incorporates the initial back-pressure (i.e. the applied cell fluid pressure minus the backpressure). Depending on the value of VCI, the fouled ballast saturation could take up to several hours, whereas for fresh ballast the value of $B$ usually approached 0.99 within 20 min. A fully drained condition was ensured by opening the drain valves and applying a sufficiently low axial shearing rate of $5.5 \mathrm{~mm} / \mathrm{min}$.

During testing, the required membrane correction was carried out according to ASTM D4767-04 (ASTM, 2002), plus other contributions from La Rochelle et al. (1988), Henkel \& Gilbert (1952) and Duncan \& Seed (1967). Considering the specimen strains, the deviator stress was corrected using the membrane properties and dimensions based on the elastic theory capturing hoop stress correction. The relatively small stress distribution attributed to specimen self-weight was considered in the effective stresses. The volumetric strain was measured using a piston within the volume change device, responding to water entering the (dilating) specimen or leaving the (compressing) specimen, and a linear variable differential transducer (LVDT) recording the piston movement (Indraratna et al., 1997). The LVDT has an accuracy of $0 \cdot 1 \mathrm{~mm}$, equivalent to $0.0083 \%$ volumetric strain. Visual inspection after testing revealed that the ballast aggregates remained fully coated with clay. Sieve analysis was carried out to measure the extent of particle breakage after each test.

\section{RESULTS AND DISCUSSION}

Stress-strain response

The upper plots of Fig. 5 illustrate the stress-strain behaviour of fouled ballast ( $\mathrm{VCI}=10-80 \%)$ in contrast to fresh ballast $(\mathrm{VCI}=0 \%)$ at increasing confining pressure. The stress-strain curves for clean ballast are similar to those for various clean ballast samples reported in earlier studies. Several plots for other aggregates, including greywacke rockfills, Bombo and Chullora basalts, are given by Indraratna et al. (2011). As expected, when the confining pressure $\left(\sigma_{3}^{\prime}\right)$ is increased from $10 \mathrm{kPa}$ to $60 \mathrm{kPa}$, the peak deviator stress and the initial deformation modulus increase for all levels of fouling. As expected, when the degree of fouling increases, the peak deviator stress decreases significantly. However, beyond $\mathrm{VCI}=25 \%$, the subsequent decrease in the peak deviator stress becomes gradual, compared with fresh ballast and for $\mathrm{VCI}=10 \%$. For $\mathrm{VCI}<25 \%$, the stress-strain curves indicate a distinct drop in post-peak strength. In contrast, at significantly higher levels of fouling, the fouled ballast exhibits a more ductile behaviour.

The stress-strain plots in Fig. 5 are plotted to axial strains at $28 \%$ (limit of actuator). The fresh ballast always shows a higher deviator stress than the fouled ballast at any given axial strain, but this difference tends to decrease at high axial strains. If the tests could be continued to larger axial strains, considerably beyond the current limit of the equipment, pronounced particle degradation and recompaction might occur, possibly approaching a critical state friction angle.

The bottom plots of Fig. 5 show the volumetric strain changes with axial strain for varying levels of fouling and increasing confining pressure. The measured data are best 


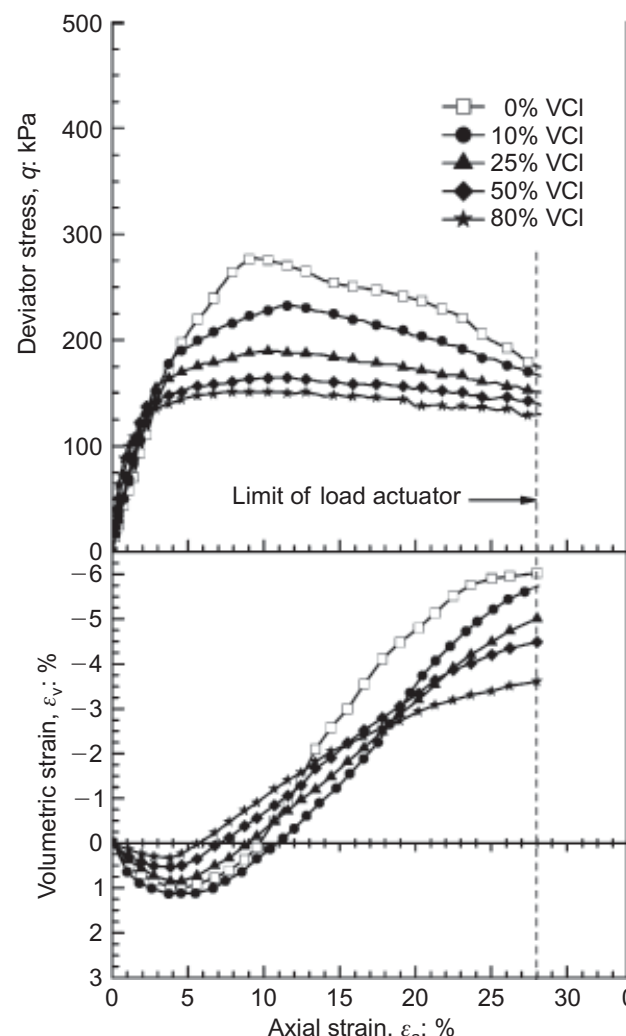

(a)

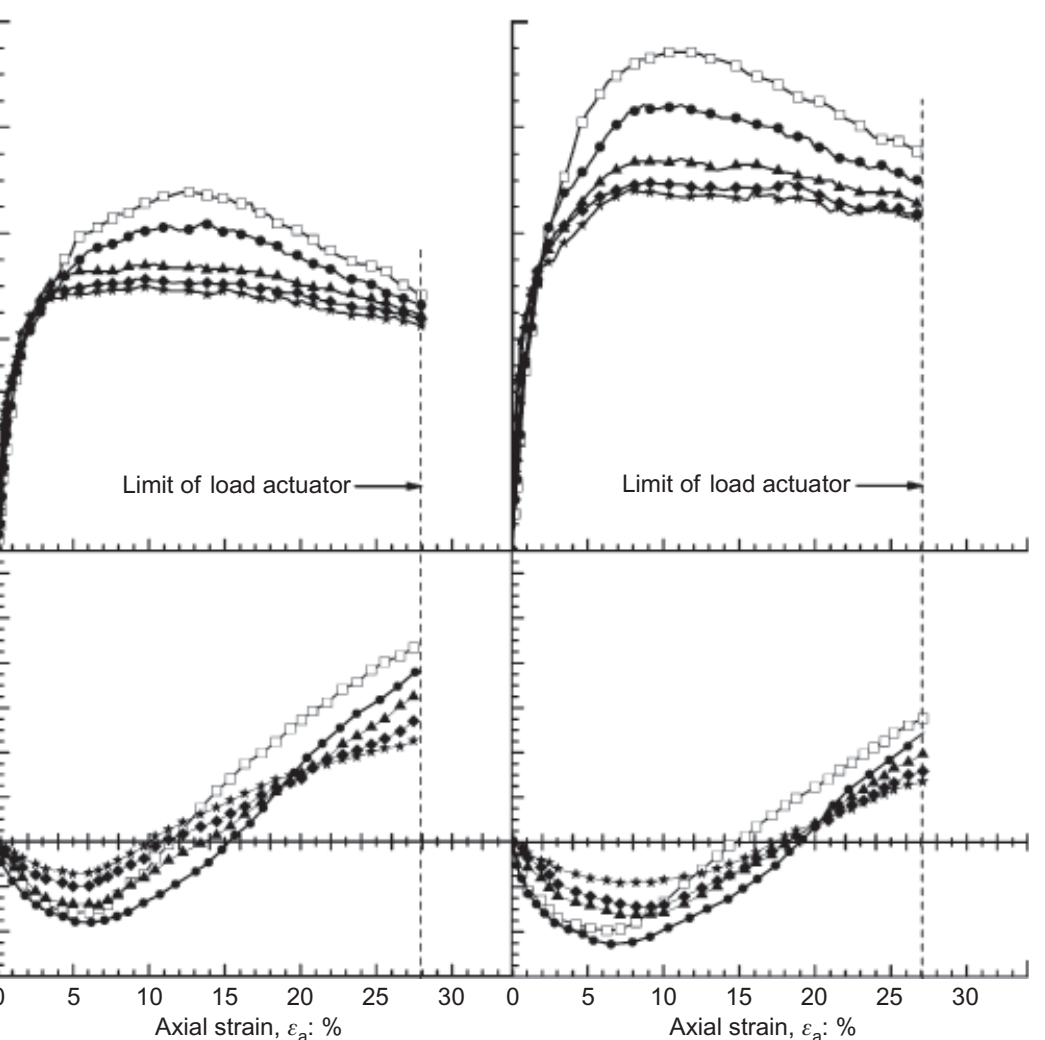

(b)

(c)

Fig. 5. Stress-strain behaviour in isotropically consolidated drained tests for different degrees of fouling at confining pressures: (a) $10 \mathrm{kPa}$; (b) $30 \mathrm{kPa}$; (c) $60 \mathrm{kPa}$

interpreted by looking at the compression zone and the dilation zone separately. In the compression zone (plotted as positive values), the increasing VCI generally shows a reduced compression of the fouled specimen, as the voids between the ballast grains are now occupied by clay acting as a void filler. Nevertheless, in the case of $\mathrm{VCI}=10 \%$, an exception is observed for all three specimens (at $\sigma_{3}^{\prime}=10$, 30 and $60 \mathrm{kPa}$ ), indicating a slightly increased compression compared with their fresh ballast counterparts. This may be attributed to the small amount of clay that is coating the ballast grains as a lubricant, thereby allowing the specimens to attain a slightly higher compression. With respect to dilation, the highly fouled specimens show a decrease in the rate and magnitude of dilation at axial strains exceeding $20 \%$, while the increase in $\sigma_{3}^{\prime}$ from $10 \mathrm{kPa}$ to $60 \mathrm{kPa}$ significantly suppresses the dilation of all specimens. Intuitively, it may be argued that the addition of kaolin in sufficient quantities may contribute to a 'binding' effect that diminishes the tendency of the aggregates to dilate. Moreover, the specimens that are highly fouled (VCI $=50 \%$ and $80 \%$ ) begin to dilate swiftly at a lower axial strain after showing a reduced compression initially, compared with clean ballast.

Figure 6 shows that the peak dilation rate of all the ballast specimens decreases with increasing VCI. It is clear that as VCI increases beyond $40 \%$ or so, the corresponding peak dilation rate remains approximately constant at all values of $\sigma_{3}^{\prime}$. In practice, track instability usually occurs as a result of excessive lateral deformation of the ballast due to low confining pressure (Selig \& Waters, 1994; Indraratna et al., 2011). Increased confining pressure decreases dilation, which makes the ballast assembly more stable (Suiker et al., 2005). If dilation during shearing can be minimised by providing sufficient field restraints (Lackenby et al., 2007), the overall stability of the track can be significantly improved. From a

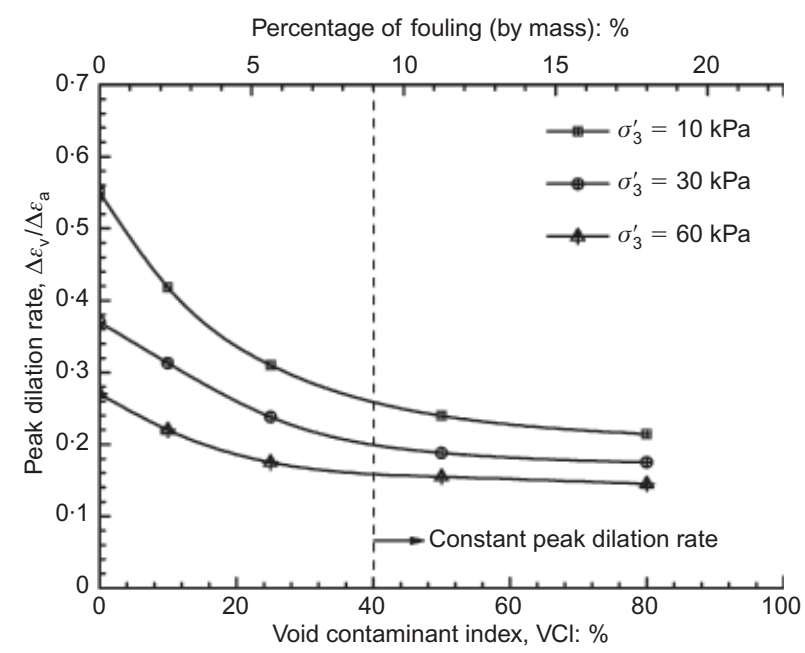

Fig. 6. Variation of peak dilation rate with VCI for clay-fouled ballast

practical point of view, Fig. 6 implies that a small amount of clay fouling ( $\mathrm{VCI}=10-20 \%$ ) can actually be beneficial in reducing the high rate of dilation of clean ballast, especially at small confining pressures, although excessive fouling would naturally pose unfavourable implications on track drainage, as well as reducing the shear strength. By plotting the peak deviator stress against VCI (Fig. 7), the following relationship that represents the normalised shear strength of fouled ballast may be used in the preliminary assessment of track conditions in view of track maintenance:

$$
\frac{q_{\text {peak }, \mathrm{f}}}{q_{\text {peak }, \mathrm{b}}}=\frac{1}{1+\beta \sqrt{\mathrm{VCI}}}
$$




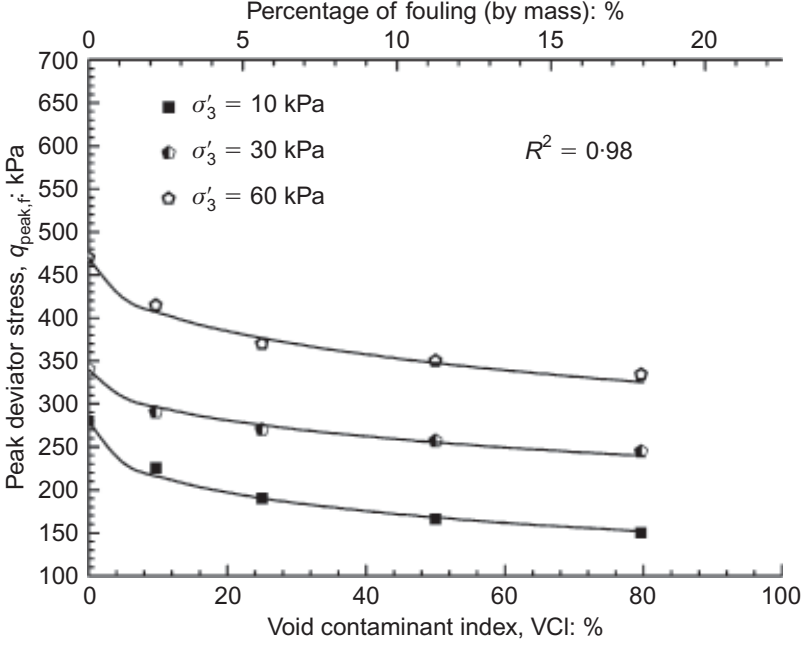

Fig. 7. Variation of peak deviator stress $q_{\text {peak,f }}$ with VCI for clayfouled ballast

where $q_{\text {peak,b }}$ and $q_{\text {peak,f }}$ are the peak deviator stresses for fresh and fouled ballast respectively, and $\beta$ is an empirical parameter, whose magnitudes are given in Table 3 for varying values of $\sigma_{3}^{\prime}$.

\section{Shear strength envelopes}

Figure 8 shows the Mohr-Coulomb diagrams of the clayfouled ballast specimens, which exhibit a non-linear shear strength envelope similar to other rockfills (Indraratna et al., $1993,1998)$. The apparent peak friction angle $\left(\phi_{\mathrm{p}}^{\prime}\right)$ corresponding to a given normal stress is readily determined by
Table 3. Values of $\boldsymbol{\beta}$ based on equation (3)

\begin{tabular}{l|c|c}
\hline $\begin{array}{l}\text { Confining pressure, } \\
\sigma_{3}^{\prime}: \mathrm{kPa}\end{array}$ & $\begin{array}{c}\text { Peak deviator stress, } \\
q_{\text {peak, } \mathrm{b}}: \mathrm{kPa}\end{array}$ & $\beta$ \\
\hline 10 & 280 & $0 \cdot 094$ \\
30 & 340 & $0 \cdot 047$ \\
60 & 470 & $0 \cdot 050$ \\
\hline
\end{tabular}

the gradient of the envelope (i.e. $\tan ^{-1} \mathrm{~d} \tau / \mathrm{d} \sigma^{\prime}$ ). Fig. 8(d) shows the peak friction angle against effective confining pressure. The peak friction angle decreases rapidly when the effective confining pressure is in the range $10-35 \mathrm{kPa}$. When VCI increases, the peak friction angle also decreases. In Fig. 8(d) the peak friction angle for clean ballast at $10 \mathrm{kPa}$ confinement is $59^{\circ}$. This is similar to the findings of Aursudkij et al. (2009) and Raymond \& Davies (1978). The angle of repose of the fresh ballast is measured as $70^{\circ}$. For freshly quarried latite basalt, commonly used as rail ballast in the suburbs of Sydney, the estimated angle of repose varies from about $63^{\circ}$ to $70^{\circ}$. For highly angular aggregates conforming to the NSW standards of ballast gradation, an angle of repose of $70^{\circ}$ is an upper bound. Fig. 9(a) plots the relationship between peak friction angle $\left(\phi_{\mathrm{p}}^{\prime}\right)$ and normal stress $\left(\sigma_{\mathrm{n}}^{\prime}\right)$ for VCI varying from 0 to $80 \%$. The normal stress was determined on the plane where the mobilised friction angle is a maximum. As expected, $\phi_{\mathrm{p}}^{\prime}$ decreases with increasing $\sigma_{\mathrm{n}}^{\prime}$. Fig. 9(b) shows the typical variation of $\phi_{\mathrm{p}}^{\prime}$ with VCI at a relatively low normal stress of $30 \mathrm{kPa}$. In general, for any given $\sigma_{\mathrm{n}}^{\prime}, \phi_{\mathrm{p}}^{\prime}$ is expected to decrease with an increase in VCI. However, at high normal stresses $\left(\sigma_{\mathrm{n}}^{\prime}>200 \mathrm{kPa}\right)$, irrespective of the value of VCI, $\phi_{\mathrm{p}}^{\prime}$ con-

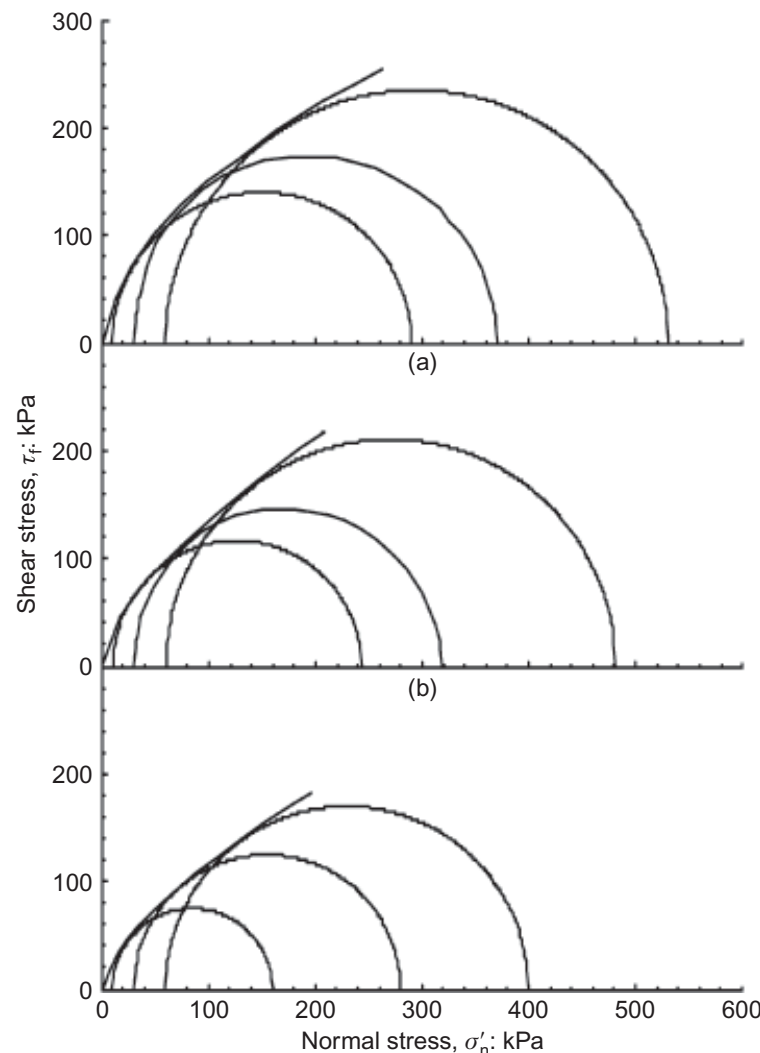

(c)

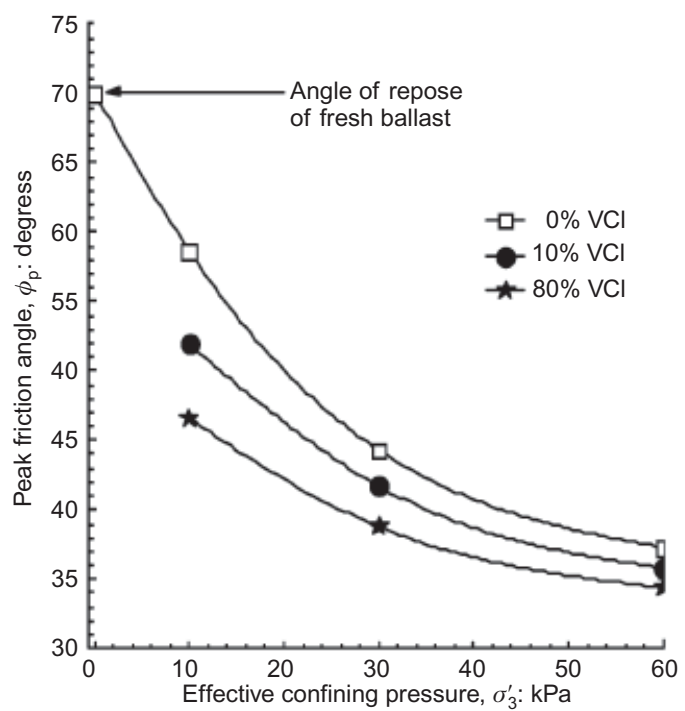

(d)

Fig. 8. Mohr-Coulomb strength envelopes for clay-fouled ballast: (a) VCI $=0 \%$; (b) $\mathrm{VCI}=10 \%$; (c) $\mathrm{VCI}=\mathbf{8 0} \%$. (d) Variation of peak friction angle $\phi_{\mathrm{p}}^{\prime}$ with effective confining pressure ( $\phi_{\mathrm{p}}^{\prime}$ determined from tangent of MohrCoulomb failure envelope) 


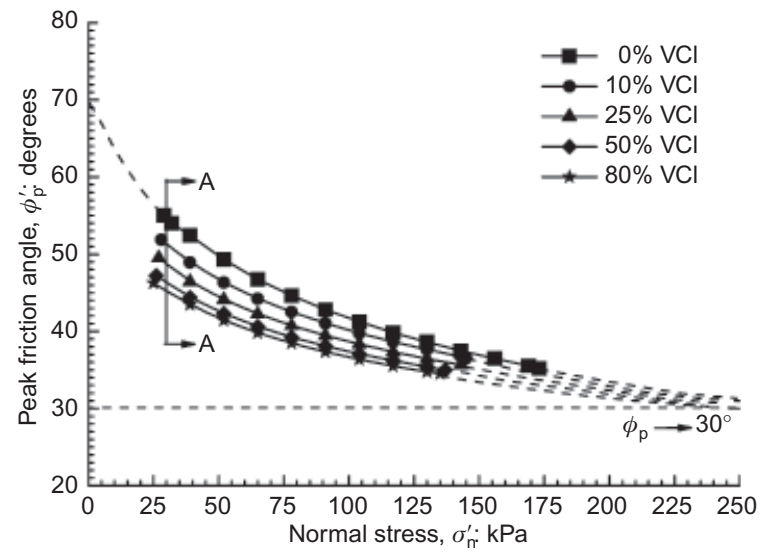

(a)

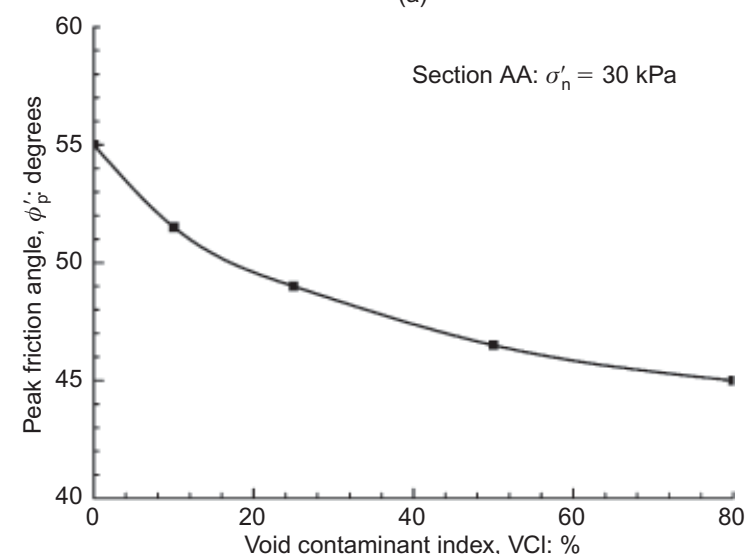

(b)

Fig. 9. (a) Apparent peak friction angle $\phi_{\mathrm{p}}^{\prime}$ against normal stress $\sigma_{\mathrm{n}}^{\prime}$ for clay-fouled ballast with different values of VCI; (b) typical variation of $\phi_{\mathrm{p}}^{\prime}$ with VCI at normal stress of $30 \mathrm{kPa}$

verges to a value in the vicinity of $30^{\circ}$. This implies that, at high normal stresses, the role of the soft plastic clay is effectively suppressed as the coarse ballast aggregates are forced to be in contact despite the voids being filled with clay.

Figure 10 shows the normalised Mohr-Coulomb peak strength envelopes for both clean and clay-fouled ballast. Here, the shear stress $(\tau)$ and the effective normal stress $\left(\sigma_{\mathrm{n}}^{\prime}\right)$ are represented as dimensionless quantities by dividing them by the uniaxial compressive strength $\left(\sigma_{\mathrm{c}}\right)$ of the parent rock. The value of $\sigma_{\mathrm{c}}$ is $130 \mathrm{MPa}$, based on the point load

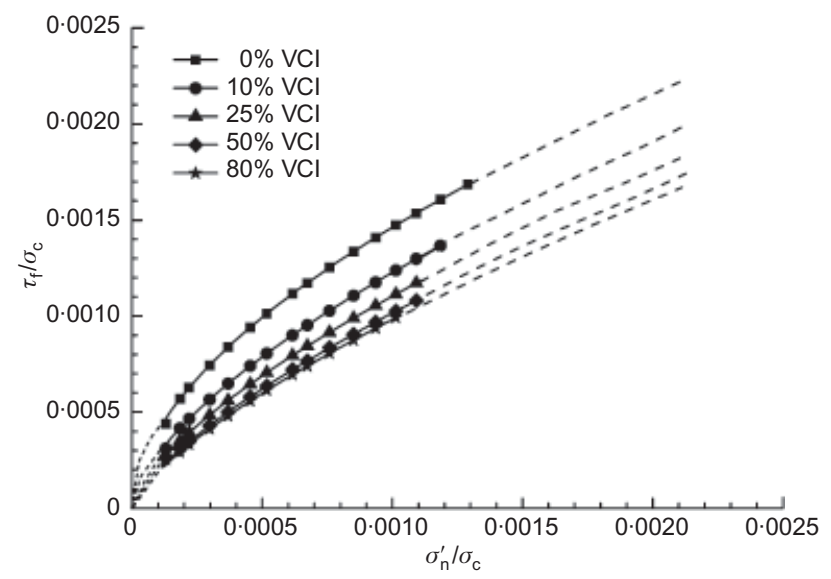

Fig. 10. Normalised strength envelopes for varying VCI test (Indraratna et al., 1998). It is clear that the normalised shear strength $\left(\tau_{\mathrm{f}} / \sigma_{\mathrm{c}}\right)$ decreases with increasing VCI. These dimensionless strength envelopes at all levels of fouling can be expressed by a non-linear equation proposed earlier by Indraratna et al. (1998)

$$
\frac{\tau_{\mathrm{f}}}{\sigma_{\mathrm{c}}}=m\left(\frac{\sigma_{\mathrm{n}}^{\prime}}{\sigma_{\mathrm{c}}}\right)^{n}
$$

where $m$ and $n$ are empirical coefficients, which vary with VCI. Fig. 10 indicates that, beyond 50\% VCI, the subsequent drop in the shear strength envelope is marginal. The values of $m$ and $n$ in equation (4) are established by best fit (regression) analysis by the expressions

$$
\begin{aligned}
& m=0.07\left[1+\tanh \left(\frac{\mathrm{VCI}}{21 \cdot 5}\right)\right] \\
& n=0.56\left[1+0 \cdot 3 \tanh \left(\frac{\mathrm{VCI}}{21 \cdot 5}\right)\right]
\end{aligned}
$$

With an increase in VCI beyond 50\%, the normalised shear strength envelopes become increasingly less curved as $m$ and $n$ converge to $0 \cdot 14$ and $0 \cdot 72$ respectively (see Fig. 11).

\section{Ballast breakage and the effect of clay fouling}

Particle breakage affects the shear strength and deformation characteristics of ballast, which in turn influences the track stability (Raymond et al., 1976; Selig \& Waters, 1994; Indraratna et al., 2011). Owing to the angular nature of quarried aggregates, ballast degradation is attributed primarily to breakage of sharp corners or attrition of asperities, while particle splitting across the body of grains may occur at high confining stresses (Indraratna et al., 1998; Lackenby et al., 2007). By sieving the ballast before and after testing, the extent of breakage can be evaluated by quantifying the differences between the PSD curves.

The extent of ballast breakage was analysed by carrying out pre-test and post-test PSD analyses. In this study, the ballast breakage index (BBI) was evaluated using the relation (Indraratna et al., 2005)

$$
\mathrm{BBI}=\frac{A}{A+B}
$$

where $A$ is the area between the PSD curves before and after testing, and $B$ is the area between the arbitrary boundary of maximum breakage and the final PSD, as illustrated in Fig. 12(a).

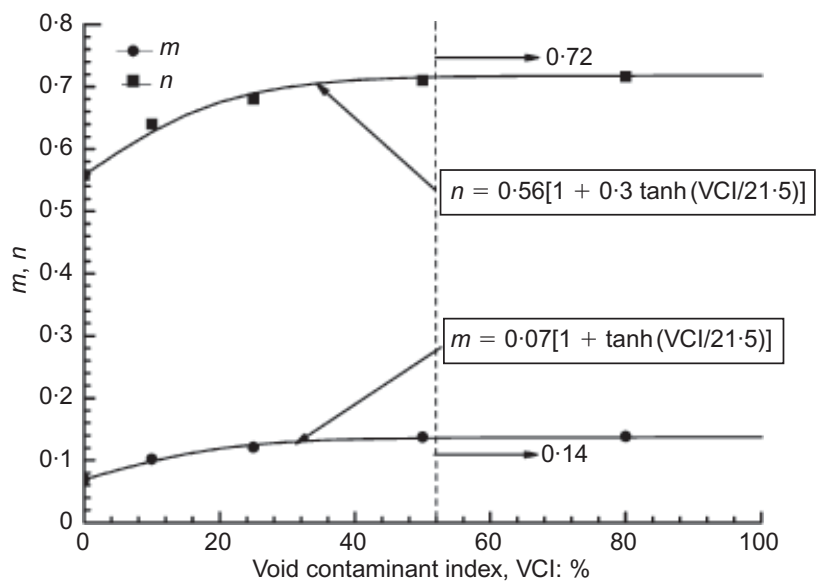

Fig. 11. Empirical strength parameters $m$ and $n$ for clay-fouled ballast at varying VCI 


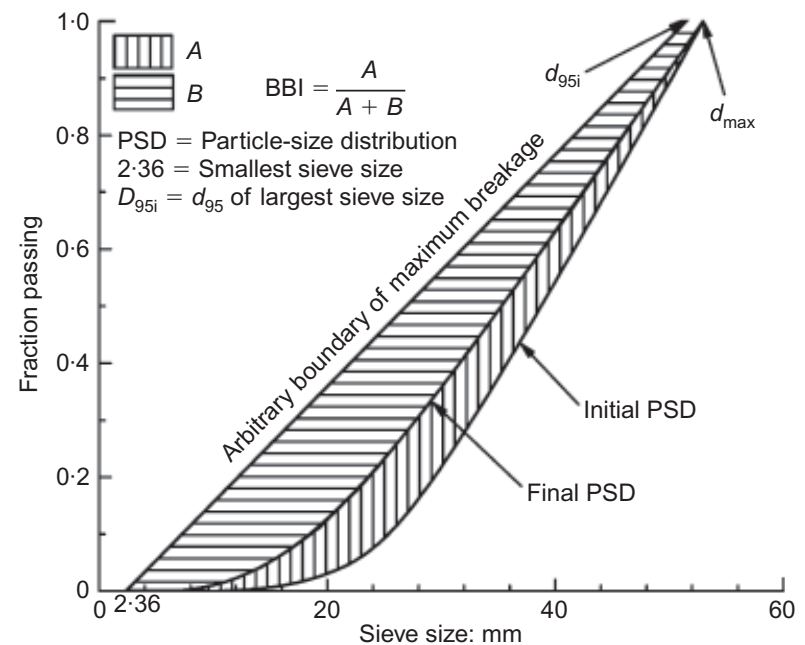

(a)

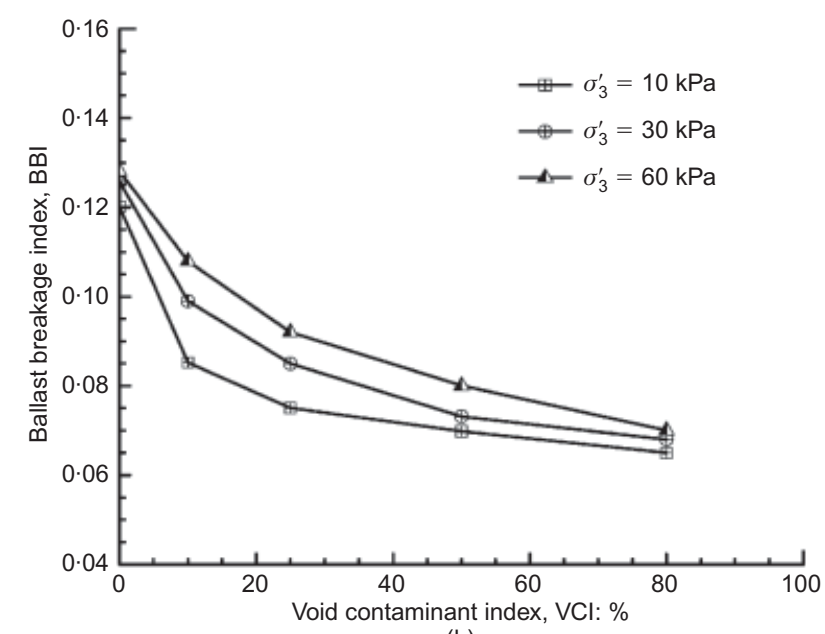

(b)

Fig. 12. (a) Determination of BBI (modified after Indraratna $e t$ al., 2005); (b) variation of BBI with VCI for clay-fouled ballast

Intuitively, it seems that clay would have a cushioning effect to thwart the harsh attrition between rough and angular particles, thereby reducing the high contact stresses and associated degradation. Fig. 12(b) illustrates the variation of BBI with VCI, which confirms that the ballast particles experience less breakage at higher values of VCI. Nevertheless, the benefits of reduced ballast degradation are offset by the drop in shear strength as the degree of fouling increases.

\section{PRACTICAL IMPLICATIONS}

From the results reported earlier, it is clear that clay fouling has significant implications for the performance of railway ballast. At low effective confining pressures $\left(\sigma_{3}^{\prime}=10-30 \mathrm{kPa}\right.$, typical of the track environment in Australia), a relatively small amount of clay fouling ( $\mathrm{VCI}=$ 10-20\%) may improve track longevity somewhat through reduced particle degradation; however, excessive fouling seriously affects the shear strength. Excessive fouling, exceeding $50 \%$ VCI, may also threaten the free-draining property of ballast, although the aspects of drainage and permeability have not been considered within the scope of this paper.

The peak friction angle $\left(\phi_{\mathrm{p}}^{\prime}\right)$ is the most important design parameter for ballast, and it is influenced by the amount of fouling (VCI) and the applied normal stress $\left(\sigma_{\mathrm{n}}^{\prime}\right)$. The Australian rail industry has been using the peak friction angle of ballast mainly obtained from direct shear tests, often conducted on reduced particle sizes $\left(d_{100}=40-\right.$ $50 \mathrm{~mm}$ ), to reduce boundary effects, adopting a parallel gradation. The range of peak friction angle values used in design varies from $45^{\circ}$ to $60^{\circ}$, depending on the ballast gradation and the test method employed. Broadly graded particle size distributions give a higher friction angle than the highly uniform gradations stipulated in Australian Standards (Indraratna et al., 2011).

The authors recommend that, where possible, the friction angle for design should be determined using large-scale triaxial tests on $300 \mathrm{~mm}$ diameter samples without having to reduce the particle sizes. Also, the confining pressure range should be kept in the realistic range $10-70 \mathrm{kPa}$, as most Australian tracks have measured internal confining pressures in the range $15-60 \mathrm{kPa}$. At relatively high confining pressures a diminishing friction angle is observed, apart from increased particle breakage (Lackenby et al., 2007). In contrast, at low confining pressures $(<15 \mathrm{kPa})$, the apparent friction angle of ballast tends to be high $\left(\phi>55^{\circ}\right)$ often approaching the angle of repose.

In low-lying estuarine plains, where 'clay pumping' may occur under wet conditions, the risk of clay fouling needs to be captured in design. A previous study (Indraratna et al., 2010a) indicated that track maintenance would be required when VCI exceeds $40 \%$. Track performance may be substantially compromised when VCI exceeds $50 \%$, with undrained conditions prevailing for VCI $>60 \%$. In such circumstances, a corresponding friction angle significantly lower than that of fresh ballast should be considered in design, unless additional geotextile and/or sub-ballast designed as a filter is placed beneath the ballast bed to prevent fouling by intruding subgrade fines. For a given ballast gradation, if the appropriate reduced friction angle is not carefully selected on the basis of the anticipated fouling levels, this may overpredict the track bearing capacity and stability. Therefore an accurate assessment of the stress-strain degradation characteristics of fouled ballast is highly beneficial for executing better maintenance and operation schemes for existing tracks, and for the preliminary design of rehabilitated tracks.

\section{CONCLUSIONS}

Rail ballast becomes contaminated or fouled by the infiltration of subgrade fines such as clay. Excessive fouling of ballast may cause differential settlements and rapid deterioration of the track, demanding regular maintenance. Therefore a proper understanding of the stress-strain degradation characteristics of fouled ballast is pertinent for the efficient maintenance and operation of tracks. In this paper, a series of isotropically consolidated drained triaxial tests using a large-scale cylindrical triaxial apparatus were conducted on clay-fouled ballast. A new parameter, the void contaminant index (VCI), which can adequately capture the extent of fouling in terms of volume-based air-voids reduction, was introduced. It was observed that increased fouling decreased the shear strength of ballast, which at high normal stress $\left(\sigma_{\mathrm{n}}^{\prime}>200 \mathrm{kPa}\right)$ remained relatively unaffected, irrespective of the VCI.

The overall volumetric response of the fouled specimens is initially compressive, but, depending on the VCI, subsequent dilation bears a significant contrast to clean ballast. It was observed that excessive fouling (VCI $>50 \%$ ) decreased both the rate and the magnitude of dilation at high axial strain, while an increase in confining pressure, $\sigma_{3}^{\prime}$ from $10 \mathrm{kPa}$ to $60 \mathrm{kPa}$ suppressed the dilation considerably. A 
relatively small amount of clay fouling $(\mathrm{VCI} \leqslant 10 \%)$ may slightly increase the initial rate of compression, and this can be attributed to the clay-coated aggregates providing a lubrication effect at smaller axial strains.

Based on the laboratory findings, a novel empirical relationship between the peak deviator stress and VCI is proposed, with the aim of assisting the practitioner in preliminary track assessment. A non-linear shear strength envelope for fouled ballast is introduced in a non-dimensional form, where the relevant shear strength coefficients could be conveniently evaluated as a function of VCI, based on the proposed empirical equations. With the increase of fouling, the ballast particles experienced less breakage, attributed to the cushioning effect of clay, which would reduce the high internal contact stresses and the associated attrition of rock particles. At high VCI $(>50 \%)$, although breakage is reduced, a considerable drop in shear strength can affect track stability and carrying capacity. The more complex aspects of clay fouling need to be carefully assessed through rigorous micromechanical studies in the future to predict the longevity and performance of ballasted tracks more accurately.

\section{ACKNOWLEDGEMENTS}

The authors are grateful to the CRC for Rail Innovation (established and supported under the Australian Government's Cooperative Research Centres programme) for the funding of this research (Project No. R3.106, 'Integrated ballast-formation-track design and analysis including the implications of ballast fouling and high impact loads'). They would also like to thank the industry partners, including RailCorp, ARTC and Queensland Rail (QR), for their keen collaboration in this study. The assistance of University of Wollongong laboratory technicians, including $\mathrm{Mr}$ Alan Grant and $\mathrm{Mr}$ Cameron Neilson, is gratefully appreciated.

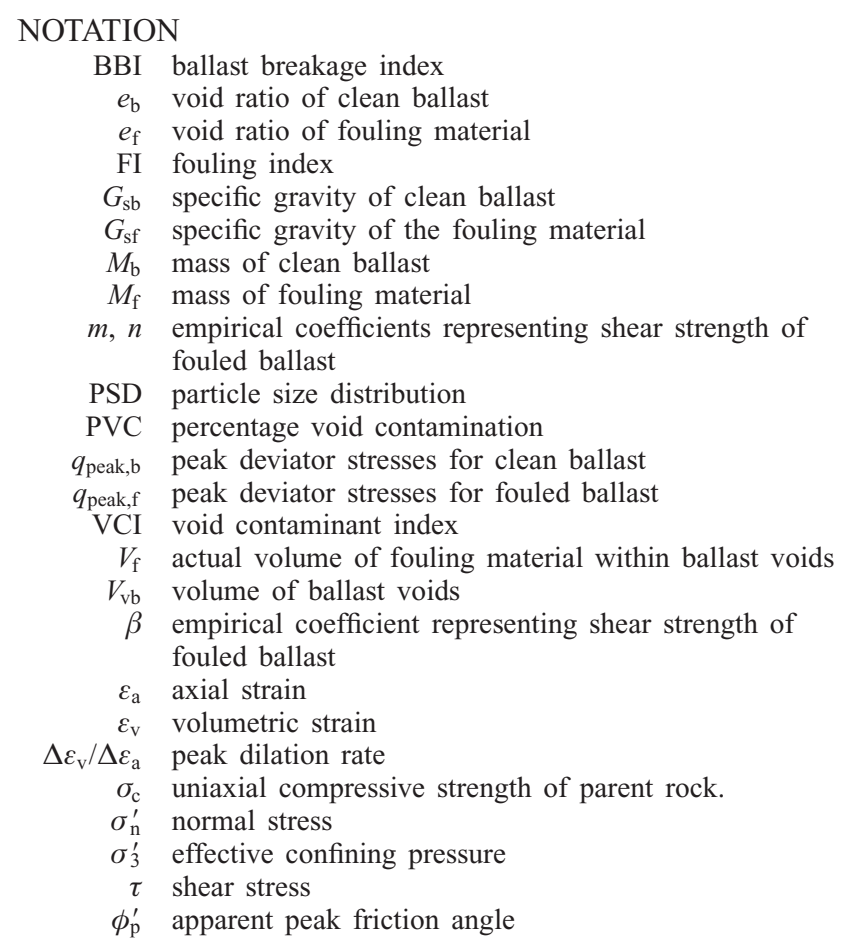

\section{REFERENCES}

ASTM (2002). Standard test method for consolidated undrained triaxial compression test for cohesive soils, ASTM D4767-02. West Conshohocken, PA, USA: ASTM International.
Aursudkij, B., McDowell, G. \& Collop, A. (2009). Cyclic loading of railway ballast under triaxial conditions and in a railway test facility. Granular Matter 11, No. 6, 391-401.

Bishop, A. W. \& Henkel, D. J. (1962). The measurement of soil properties in the triaxial test. London, UK: Arnold.

Budiono, D. S., McSweeney, T., Dhanasekar, M. \& Gurung, N. (2004). The effect of coal dust fouling on the cyclic behaviour of railtrack ballast. In Proceedings of the international conference on cyclic behaviour of soils and liquefaction phenomena, Bochum, pp. 627-632. London, UK: Taylor \& Francis Group.

Duncan, J. M. \& Seed, H. B. (1967). Corrections for strength test data. J. Soil Mech. Found. Div. ASCE 93, No. SM5, 121-137.

Feldman, F. \& Nissen, D. (2002). Alternative testing method for the measurement of ballast fouling. Proceedings of the RTSA conference on railway engineering, Wollongong, NSW, pp. 101109.

Giannakos, K. (2010). Loads on track, ballast fouling, and life cycle under dynamic loading in railways. J. Transp. Engng 136, No. $12,1075-1084$

Henkel, D. J. \& Gilbert, G. D. (1952). The effect of the rubber membrane on the measured triaxial compression strength of clay samples. Géotechnique 3, No. 1, 20-29, http://dx.doi.org/ 10.1680/geot.1952.3.1.20.

Huang, H. \& Tutumluer, E. (2011). Discrete element modeling for fouled railroad ballast. Const. Build. Mater. 25, No. 8, 33063312 .

Huang, H., Tutumluer, E. \& Dombrow, W. (2009). Laboratory characterization of fouled railroad ballast behavior. Transp. Res. Rec., No. 2117, 93-101.

Huang, H., Tutumluer, E., Hashash, Y. \& Ghaboussi, J. (2010). Laboratory validation of coal dust fouled ballast discrete element model. Proc. GeoShanghai 2010 Int. Conf., 305-313.

Indraratna, B., Wijewardena, L. S. S. \& Balasubramaniam, A. S. (1993). Large-scale triaxial testing of greywacke rockfill. Géotechnique 43, No. 1, 37-51, http://dx.doi.org/10.1680/geot.1993. 43.1.37.

Indraratna, B., Ionescu, D., Christie, H. D. \& Choudhury, R. N. (1997). Compression and degradation of railway ballast under one-dimensional loading. Aust. Geomech. 32, No. 4, 48-61.

Indraratna, B., Ionescu, D. \& Christie, D. (1998). Shear behaviour of rail ballast on large scale triaxial testing. J. Geotech. Geoenviron. Engng ASCE 124, No. 5, 439-449.

Indraratna, B., Lackenby, J. \& Christie, D. (2005). Effect of confining pressure on the gradation of ballast under cyclic loading. Géotechnique 55, No. 4, 325-328, http://dx.doi.org/10.1680/ geot.2005.55.4.325.

Indraratna, B., Nimbalkar, S. S. \& Tennakoon, N. (2010a). The behaviour of ballasted track foundations: track drainage and geosynthetic reinforcement Proc. GeoFlorida 2010 Conf. on Advances in Analysis, Modeling, \& Design, ASCE, Orlando, FL, $2378-2387$.

Indraratna, B., Nimbalkar, S., Christie, D., Rujikiatkamjorn, C. \& Vinod, J. S. (2010b). Field assessment of the performance of a ballasted rail track with and without geosynthetics J. Geotech. Geoenviron. Engng ASCE 136, No. 7, 907-917.

Indraratna, B., Salim, W. \& Rujikiatkamjorn, C. (2011). Advanced rail geotechnology: Ballasted track, pp. 2-7, 81-87. Boca Raton, FL, USA: CRC Press.

La Rochelle, P., Leroueil, S., Trak, B., Blais-Leroux, L. \& Tavenas, F. (1988). Observational approach to membrane and area corrections in triaxial tests. In Advanced triaxial testing of soil and rock (eds R. T. Donaghe, R. C. Chaney and M. L. Silver), ASTM STP 977, pp. 715-731. West Conshohocken, PA, USA: American Society for Testing and Materials.

Lackenby, J., Indraratna, B., McDowell, G. R. \& Christie, D. (2007). Effect of confining pressure on ballast degradation and deformation under cyclic triaxial loading. Géotechnique 57, No. 6, 527-536, http://dx.doi.org/10.1680/geot.2007.57.6.527.

Le Pen, L. \& Powrie, W. (2011). Contribution of base, crib, and shoulder ballast to the lateral sliding resistance of railway track: a geotechnical perspective. J. Rail Rapid Transit, Proc. IMechE Part F 225, No. 2, 113-128.

Lim, W. L. \& McDowell, G. R. (2005). Discrete element modelling of railway ballast. Granular Matter 7, No. 1, 19-29.

Lu, M. \& McDowell, G. R. (2006). Discrete element modelling of ballast abrasion. Géotechnique 56, No. 9, 651-655, http:// 
dx.doi.org/10.1680/geot.2006.56.9.651.

Marachi, N. D., Chan, C. K. \& Seed, H. B. (1972). Evaluation of properties of rockfill materials. J. Soil Mech. Found. Div. ASCE 98, No. SM1, 95-114

Priest, J. A., Powrie, W., Yang, L. A., Grabe, P. J. \& Clayton, C. R. I. (2010). Measurements of transient ground movements below a ballasted railway line. Géotechnique 60, No. 9, 667-677, http:// dx.doi.org/10.1680/geot.7.00172.

Raymond, G. P. \& Davies, J. R. (1978). Triaxial tests on dolomite railroad ballast. Journal Geotech. Engng Div. ASCE 104, No. 6, $737-751$.
Raymond, G. P., Lake, R. W. \& Boon, C. J. (1976). Stresses and deformations in railway track, CIGGT Report No. 76-11. Ontario, Canada: Queen's University Press.

Selig, E. T. \& Waters, J. M. (1994). Track technology and substructure management. London, UK: Thomas Telford.

Standards Australia (1996). Aggregates and rock for engineering purposes, AS2758.7: Part 7: Railway ballast. Sydney, NSW, Australia: Standards Australia.

Suiker, A. S. J., Selig, E. T. \& Frenkel, R. (2005). Static and cyclic triaxial testing of ballast and subballast. J. Geotech. Geoenviron. Engng ASCE 131, No. 6, 771-782. 